\author{
Нікішина О.В. \\ доктор економічних наук, старший науковий співробітник \\ завідувач відділу ринкових механізмів та структур \\ Інститут проблем ринку та економіко-екологічних досліджень НАН України \\ Французький бульвар, 29, м. Одеса, Україна, 65044 \\ E-mail: ksenkych@gmail.com \\ ORCID ID: 0000-0002-7172-3551
}

\title{
МЕТОДИЧНІ ПОЛОЖЕННЯ ДІАГНОСТИКИ ЕФЕКТИВНОСТІ ФУНКЦІОНУВАННЯ ЛОГІСТИЧНИХ ЛАНЦЮГІВ ТОВАРНИХ РИНКІВ
}

Стаття присвячена обґрунтуванню методичного забезпечення для діагностики ефективності функціонування ринкових ланцюгів на базі синтезу чотирьох наукових підходів: відтворювального, регуляторного, концепцій діаграми збалансованих переваг і сталого розвитку. Встановлено логічну послідовність формування системи збалансованих показників у взаємозв'язку з концептуальним базисом та етапами оціночних процедур. Розглянуто складові системи збалансованих показників за п'яти напрямами діагностики: (1) фрормування, перерозподіл та структура доданої вартості у ланковому та ринковому вимірі; (2) ресурсовикористання та часові параметри ланцюга; (3) потужність руху внутрішніх і зовнішніх матеріальних потоків у ринковому ланцюгу; (4) тенденції сталого розвитку логістичних ланцюгів; (5) якість логістичного обслуговування в ринку. Обґрунтовано низку вимог до діагностичних показників, доцільність їх включення в систему. Визначено переваги запропонованих методичних положень діагностики ефективності функціонування логістичних ланцюгів товарних ринків, їх користувачі та сфери прикладного використання.

Ключові слова: ефективність, діагностика, ринок, логістичний ланцюг, методичні положення, додана вартість, система збалансованих показників.

This work is licensed under a Creative Commons Attribution 4.0 International License http://creativecommons.org/licenses/by/4.0/

Постановка проблеми та їі зв'язок з важливими науковими та практичними завданнями. Завдання подолання наслідків пандемічної кризи актуалізує інноваційні розробки у площині забезпечення відтворювального розвитку стратегічних товарних ринків України, у т.ч. шляхом формування їх ефективних логістичних ланцюгів. Невід'ємною складовою таких розробок є управлінські інновації, орієнтовані на впровадження нових механізмів та інструментів управління формуванням і трансформацією логістичних ланцюгів товарних ринків (далі - ЛЛТР), що базуються на системному методичному забезпеченні. Проведений аналіз найбільш поширених методик до оцінки ефективності логістичних систем свідчить про ïх різноплановість, неоднорідність індикаторів, об'єднаних у групи, певні переваги і обмеження прикладного використання. Водночас більшість методик стосуються, передусім, мікрологістичних систем, тоді як діагностика ефективності мезо- і макрологістичних систем, зокрема, ЛЛТР, обумовлює необхідність розробки нового методичного забезпечення із врахуванням цільових стратегічних орієнтирів таких систем та нестабільності зовнішнього середовища. Актуаль- ність обраної теми обумовлена необхідністю розробки методичного базису діагностики ефективності ЛЛТР, тому що це підгрунтя $\epsilon$ науковою основою для впровадження нових управлінських механізмів і заходів.

Аналіз останніх публікацій по проблемі. Методичні питання оцінки ефективності мікрологістичних систем знайшли відображення в працях вітчизняних й іноземних науковців, зокрема, Вітковські Я. [1], Гурч Л.М., Кочубея Д. [2], Кристофера М., Міротіна Л.Б, Пономарьової Ю.В., Сагайдак-Нікітюка P.В., Сумця О.М. [3, 4, 5], Уотерса Д. [6] та інших учених. Найбільш близьким до цільових орієнтирів ринкової логістики $\epsilon$ методичний підхід Я. Вітковські, що передбачає виокремлення критерію максимізації доданої вартості за існуючих витрат [1]. До речі, це єдиний підхід, що має відтворювальний вимір, корелюючи таким чином із відтворювальними принципами формування ефективних ЛЛТР [7]. Серед множин економічних індикаторів найбільш прийнятною для використання на макрорівні (після трансформаціі) є система загальних і часткових індикаторів, запропонована проф. О.М. Сумцем [3, с. 41].

\footnotetext{
* Публікацію підготовлено в межах виконання НДР «Формування ефективної логістики товарних ринків» (№ державної реєстрації 0119U000227).
} 
Нині завдання оцінки ефективності функціонування ЛЛТР з урахуванням економічних інтересів не тільки окремих суб'єктів, а й інтегрованого ланцюга в цілому, залишається невирішеним, актуалізуючи необхідність нових досліджень у даному напрямi.

Формулювання цілей дослідження. Мета статті - розробка методичного базису діагностики ефективності функціонування ЛЛТР, як підгрунтя для обгрунтування адаптивних механізмів і заходів управлінського впливу.

Виклад основних результатів та їх обгрунтування. Розроблені автором методичні положення діагностики ефективності функціонування ЛЛТР включили три етапи: (1) ідентифікація релевантного ринку, що передбачає визначення товарних, територіальних та часових меж ринку, його ємності, ланкової структури та головних суб'єктів; (2) діагностика ефективності ЛЛТР за допомогою системи збалансова- них показників (далі - СЗП); (3) оцінка міжланкових балансів показників ефективності, агрегований висновок про стан і проблеми ринкової логістики. Розглянемо другий етап більш детально.

Логіка формування СЗП для діагностики ефективності ринкової логістики у взаємозв'язку з концептуальним базисом та етапами оціночних процедур графічно відображена на рис. 1. Сукупність показників, які відображають ступінь досягнення стратегічної інтегрованої мети ринкового ланцюга забезпечення розширеного відтворення товароруху в ринку, - запропоновано об'єднати у 5 груп. За своїм економічним змістом виділені групи показників близькі до певної концепції (відтворювальної, діаграми збалансованих переваг, сталого розвитку) і водночас пов'язані між собою єдиним цільовим орієнтиром доданою вартістю, генеруючи зв'язки між концепціями.

Стратегічна інтегрована мета ЛЛТР - розширене відтворення товароруху в ринку

Головний критерій ефективності ЛЛТР - оптимізація загальної ринкової доданої вартості

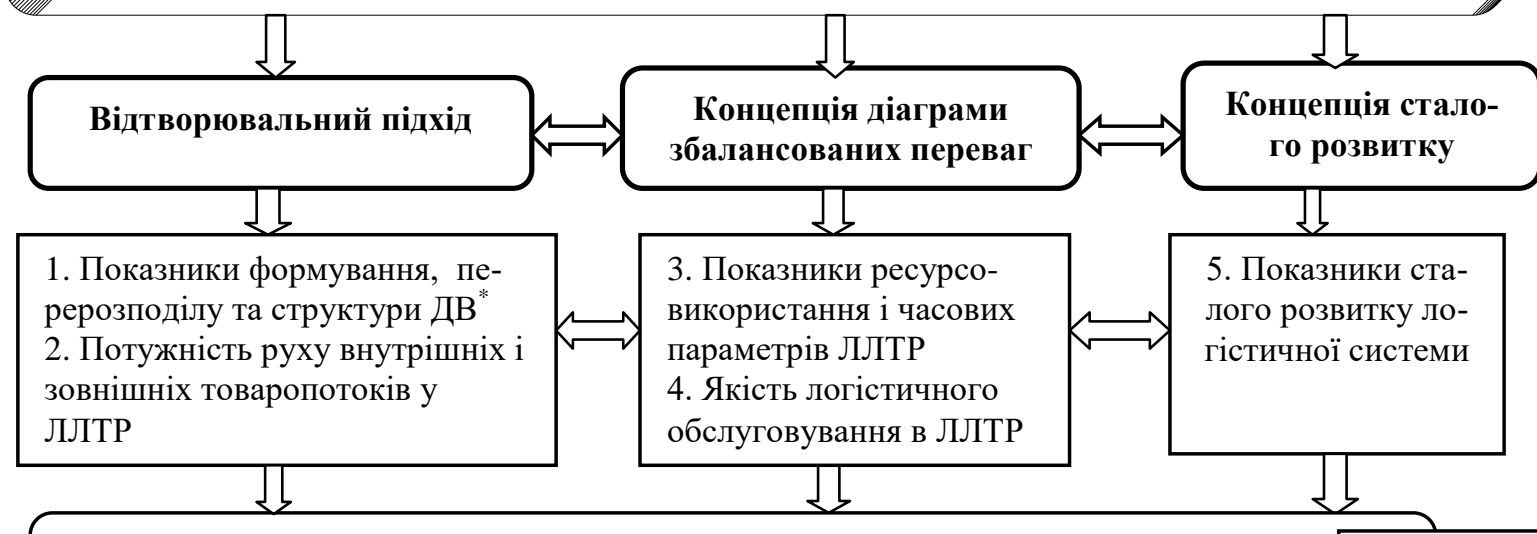

Системна діагностика стану функціонування ЛЛТР, встановлення причинно-

наслідкових зв'язків між показниками, діагностика інституційного середовища

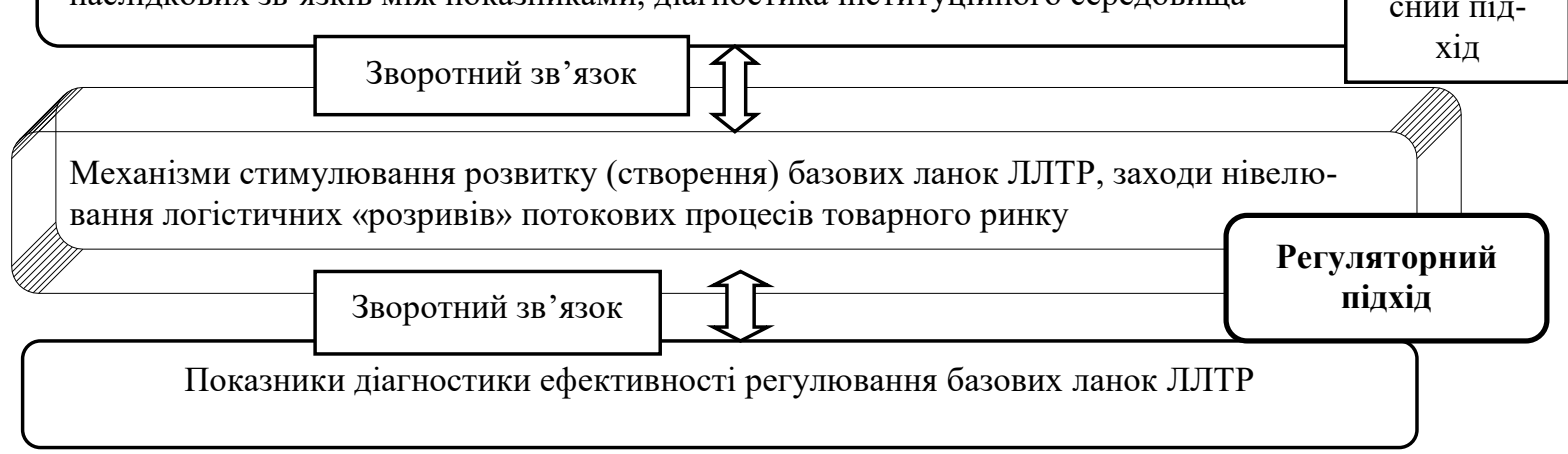

*ДВ - додана вартість

Рис. 1. Логіка формування системи збалансованих показників для діагностики ефективності ЛЛТР* *авторська розробка

У ході виборі показників для діагностики ефективності ЛЛТР потрібно забезпечити їх відповідність низці вимог (рис. 2). Так, впровадження комплексного підходу до діагностики передбачає збалан- сованість кількісних і якісних оціночних показників. До складу СЗП доцільно включити низку структурних показників, які діагностують структурні диспропорції потокових процесів товарного ринку, зміни 
міжланкових пропорцій товароруху в матеріалопровідній системі та дозволяють визначати логістичні «розриви». Вимога транспарентності, тобто відкритості й прозорості для стейкхолдерів, обумовлена необхідністю діагностики зовнішнього середовища ЛЛТР різними іiі учасниками для врахування впливу зовнішніх чинників у логістичних стратегіях. Наявність інформаційної бази для розрахунку СЗП забезпечує прикладне значення методичних положень $\mathrm{i}$ формує аналітичний фундамент для прийняття управлінських рішень різних рівнів.

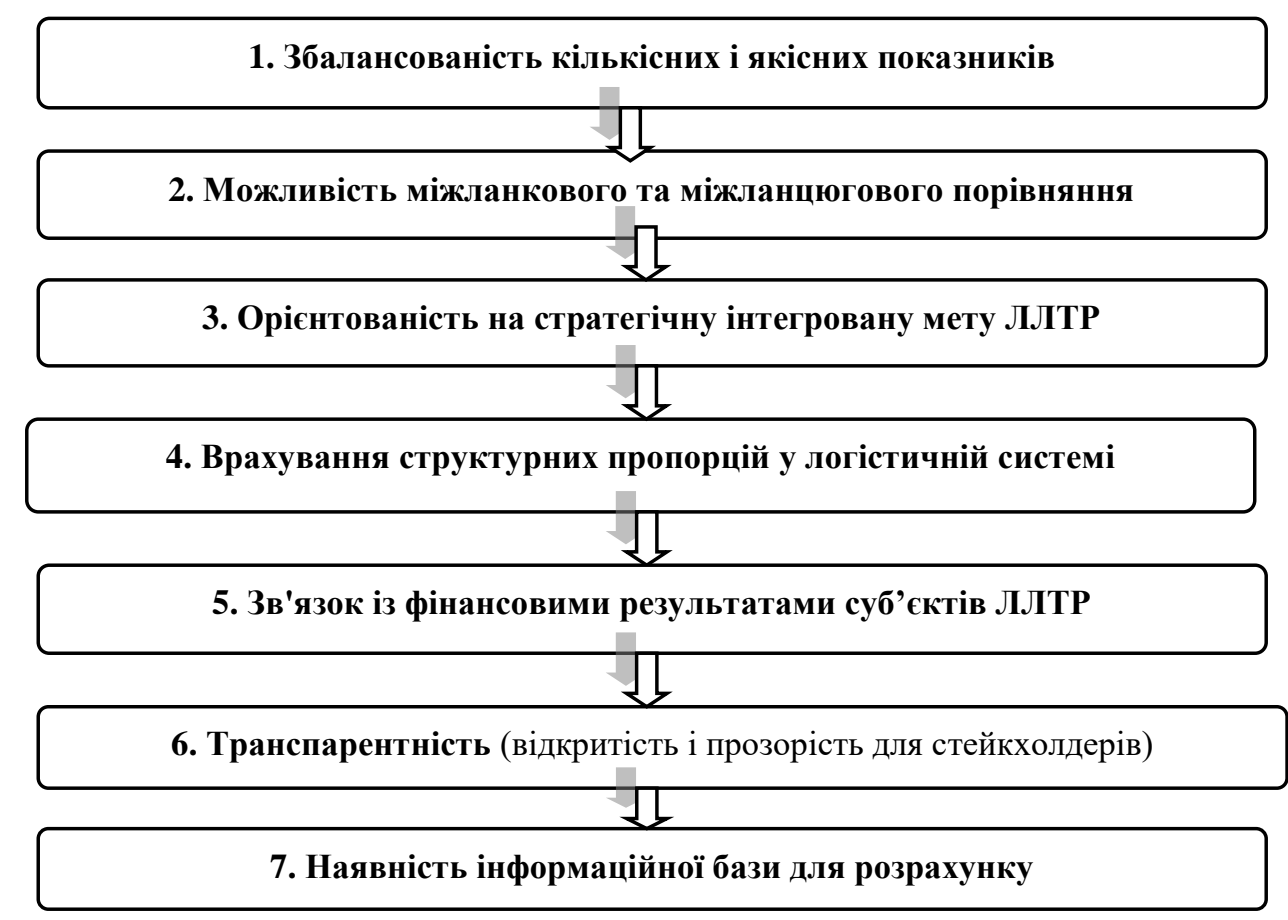

Рис. 2. Вимоги до показників діагностики ефективності функціонування ЛЛТР* *авторська розробка

Враховуючи наведені вище вимоги (див. рис. 2), відповідність стратегічній меті та цільовому критерію ефективності ЛЛТР, взаємозалежність різних концепцій (див. рис. 1), особливості комплексного підходу до діагностики, автором запропоновано
СЗБ для оцінки ефективності функціонування ринкових ланцюгів, що включили 5 груп діагностичних показників. Компоненти (підгрупи), їх характеристики та формули розрахунку першої групи показників узагальнено в табл.1.

Таблиця 1

Система збалансованих показників для діагностики ефективності формування, перерозподілу й структури доданої вартості в ЛЛТР*

\begin{tabular}{|c|c|c|c|}
\hline Підгрупи & Показники & Характеристика & Формула розрахунку \\
\hline 1 & 2 & 3 & 4 \\
\hline \multirow{4}{*}{ 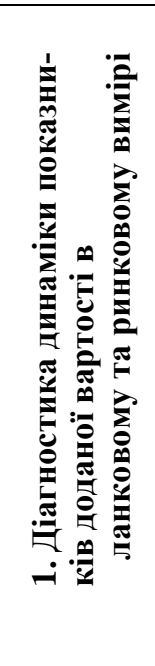 } & 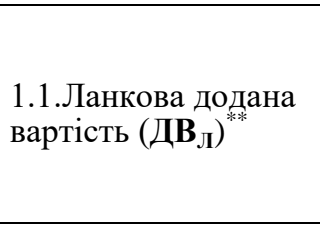 & $\begin{array}{l}\text { Відображає реальний внесок } \\
\text { кожної ланки в створення до- } \\
\text { даної вартості в ринковому } \\
\text { ланцюгу }\end{array}$ & 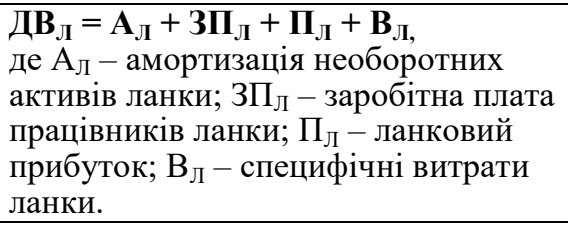 \\
\hline & $\begin{array}{l}\text { 1.2.Ринкова додана } \\
\text { вартість (ДВ })\end{array}$ & $\begin{array}{l}\text { Загальна величина новоство- } \\
\text { реної вартості в логістичному } \\
\text { ланцюгу товарного ринку }\end{array}$ & 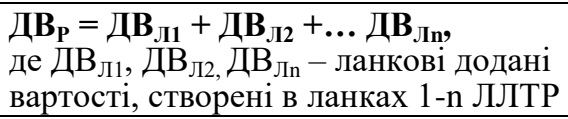 \\
\hline & $\begin{array}{l}\text { 1.3. Частка ДВ у ви- } \\
\text { пуску продукції } \\
\left(\mathbf{Ч}_{\text {дв }}\right)\end{array}$ & $\begin{array}{l}\text { Питома вага ДВ (ланкової та } \\
\text { ринкової) у випуску продукції } \\
\text { (певної ланки або ринкового } \\
\text { ланцюга в цілому) }\end{array}$ & $\begin{array}{l}\mathbf{Y}_{\text {ДВл }}=\text { ДВ } \mathbf{B}_{Л} / \mathbf{B}_{л} ; \\
\mathbf{Y}_{\text {Двр }}=\text { ДВ } / \mathbf{B}_{\mathbf{p}}, \\
\text { де } \mathbf{B}_{л}, \mathbf{B}_{\mathbf{p}}-\text { виПуск продукції (у вар- } \\
\text { тісному виразі) ланки, ринкового } \\
\text { ланцюга }\end{array}$ \\
\hline & $\begin{array}{l}\text { 1.4. Відтворювальна } \\
\text { рентабельність про- } \\
\text { дукції }\left(\mathbf{P B}_{Л}\right)^{* *}\end{array}$ & $\begin{array}{l}\text { Обсяг доданої вартості, що } \\
\text { припадає на } 1 \text { грн. витрат на } \\
\text { виробництво продукції (пос- } \\
\text { луг) певної ланки ЛЛТР }\end{array}$ & $\begin{array}{l}\mathbf{P B}_{\text {л }}=\text { ДB }_{\text {л }} / \mathbf{B T}_{л}, \\
\text { де } \mathbf{B T}_{\text {л }}-\text { витрати на виробництво } \\
\text { продукції (послуг) певної ланки } \\
\text { ЛЛТР }\end{array}$ \\
\hline
\end{tabular}


Продовження табл. 1

\begin{tabular}{|c|c|c|c|c|}
\hline Підгрупи & Показники & \multicolumn{2}{|c|}{ Характеристика } & Формула розрахунку \\
\hline & $\begin{array}{l}\text { 1.5. Рентабельність } \\
\text { продукції (послуг) }\end{array}$ & \multicolumn{2}{|c|}{$\begin{array}{l}\text { Величина прибутку на } 1 \text { грн. ви- } \\
\text { трат на виробництво продукції } \\
\text { (послуг) ланки }\end{array}$} & $\begin{array}{l}\mathbf{P}_{л}=\mathbf{\Pi}_{л} / \mathbf{B T}_{л}, \\
\text { де П } \mathbf{\Pi}_{л}-\text { прибуток від реалізації } \\
\text { продукції (послуг) певної ланки } \\
\text { ЛЛТР }\end{array}$ \\
\hline & $\begin{array}{l}\text { 1.6. Податкомісткість } \\
\text { доданої вартості } \\
(\text { Пдв) })^{* *}\end{array}$ & \multicolumn{2}{|c|}{$\begin{array}{l}\text { Величина податкових надхо- } \\
\text { джень, що припадає на } 1 \text { грн. ДВ } \\
\text { у ланковому та ринковому розрізі }\end{array}$} & $\begin{array}{l}\boldsymbol{\Pi}_{\text {двл }}=\boldsymbol{\Pi}_{л} / \text { ДВ }_{\text {л }} ; \\
\boldsymbol{\Pi}_{\text {Двр }}=\Pi_{\mathbf{p}} / \text { ДВ } \\
\text { де Пл, Пл - Податкові надхо- } \\
\text { дження від суб'єктів ланки, рин- } \\
\text { кового ланцюга }\end{array}$ \\
\hline & $\begin{array}{l}\text { 1.7. Додана вартість } \\
\text { реінвестована } \\
(\text { ДВ })^{* *}\end{array}$ & \multicolumn{2}{|c|}{$\begin{array}{l}\text { Частина новоствореної вартості, } \\
\text { спрямованої на ресурсне забезпе- } \\
\text { чення наступного процесу відт- } \\
\text { ворення певної ланки або ринко- } \\
\text { вого ланцюга в цілому }\end{array}$} & 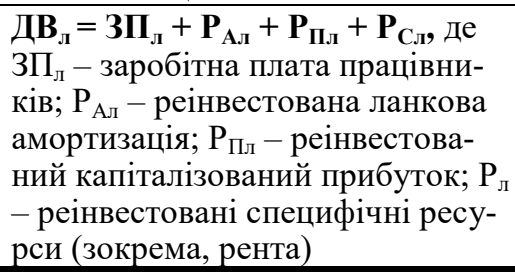 \\
\hline \multirow{5}{*}{ 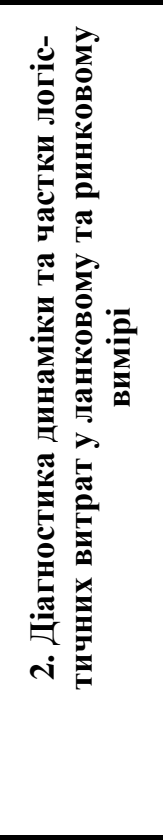 } & $\begin{array}{l}\text { 2.1. Ланкові логістич- } \\
\text { ні витрати (ЛВ })\end{array}$ & \multicolumn{3}{|c|}{ 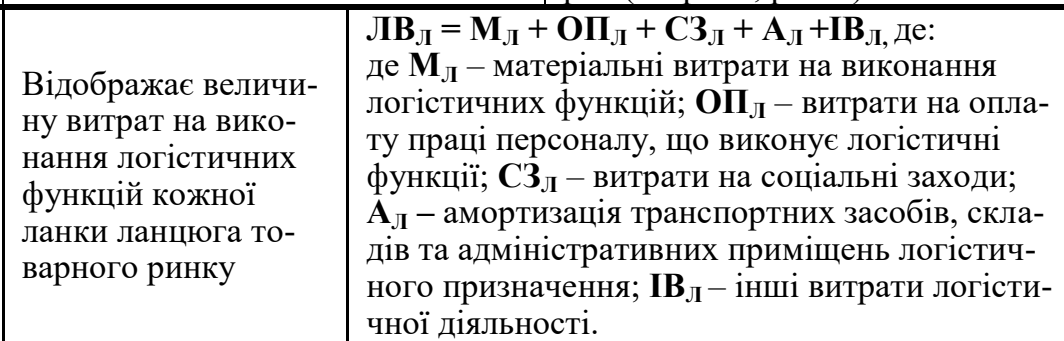 } \\
\hline & $\begin{array}{l}\text { 2.2.Ринкові логістичні } \\
\text { витрати (ЛВ })\end{array}$ & \multicolumn{2}{|c|}{$\begin{array}{l}\text { Загальна величина логістичних } \\
\text { витрат у логістичному ланцюгу } \\
\text { товарного ринку }\end{array}$} & $\begin{array}{l}\text { ЛВ }_{\mathbf{P}}=\text { ЛВ }_{\text {Л1 }}+\text { ЛВ }_{\text {Л2 }}+\ldots . \text { ЛВ } \\
\text { де ЛВ Л1 }, \text { ЛВ Л2, ЛВ Лn }- \text { ланкові } \\
\text { логістичні витрати в ланках 1-n } \\
\text { ЛЛТР }\end{array}$ \\
\hline & $\begin{array}{l}\text { 2.3. Частка ЛВ у ви- } \\
\text { пуску продукції } \\
\left(\mathbf{Ч}_{\text {Лв }}\right)\end{array}$ & \multicolumn{2}{|c|}{$\begin{array}{l}\text { Питома вага ЛВ (ланкових та } \\
\text { ринкових) у випуску продукції } \\
\text { (ланки або ринкового ланцюга) }\end{array}$} & 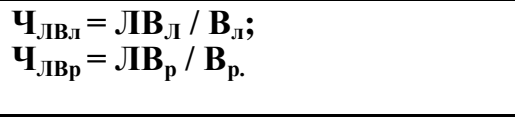 \\
\hline & $\begin{array}{l}\text { 2.4. Частка ЛВ у зага- } \\
\text { льних витратах (Ч } \text { Лвз })\end{array}$ & \multicolumn{2}{|c|}{$\begin{array}{l}\text { Обсяг логістичних витрат, що } \\
\text { припадає на } 1 \text { грн. витрат на ви- } \\
\text { робництво продукції (послуг) } \\
\text { певної ланки ЛЛТР }\end{array}$} & 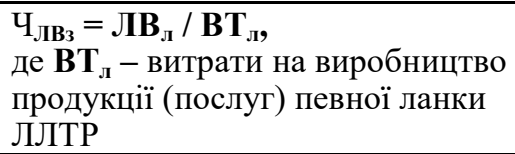 \\
\hline & $\begin{array}{l}\text { 2.5. Частка ЛВ у до- } \\
\text { даній вартості }\left(\mathbf{Ч}_{\text {ЛВдв }}\right)^{* *}\end{array}$ & \multicolumn{2}{|c|}{$\begin{array}{l}\text { Логістична складова новостворе- } \\
\text { ної вартості кожної ланки ЛЛТР }\end{array}$} & $\mathbf{Y}_{\text {ЛВдв }}=Л_{\text {ЛВ }} /$ ДВ \\
\hline \multirow{7}{*}{ 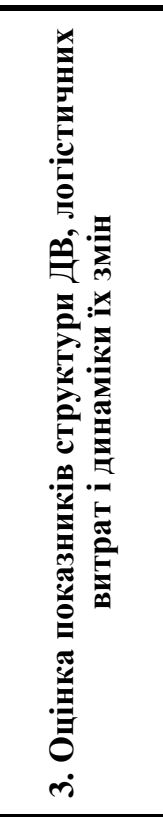 } & $\begin{array}{l}\text { 3.1. Частка прибутку } \\
\left(\mathbf{Ч}_{\Pi}\right)\end{array}$ & \multicolumn{2}{|c|}{$\begin{array}{l}\text { Частка прибутку у доданій вар- } \\
\text { тості, створюваній певною лан- } \\
\text { кою ринку }\end{array}$} & $\begin{array}{l}\mathbf{Y}_{\boldsymbol{\Pi}}=\boldsymbol{\Pi}_{л} / \text { ДВ } \\
\text { де } \Pi_{л}-\text { ланковий прибуток. }\end{array}$ \\
\hline & $\begin{array}{l}\text { 3.2. Частка амортиза- } \\
\text { ції }\left(\mathbf{Ч}_{\mathbf{A}}\right)\end{array}$ & \multicolumn{2}{|c|}{$\begin{array}{l}\text { Частка витрат на відновлення } \\
\text { необоротних активів певної лан- } \\
\text { ки ЛЛТР }\end{array}$} & $\begin{array}{l}\mathbf{Y}_{\text {Л }}=\mathbf{A}_{\text {Л }} / \text { ДВ } \\
\text { де } \mathrm{A}_{\text {л }} \text { - амортизація необоротних } \\
\text { активів певної ланки ЛЛТР }\end{array}$ \\
\hline & 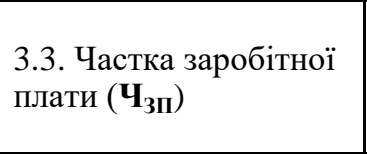 & \multicolumn{2}{|c|}{$\begin{array}{l}\text { Частка особистих доходів пра- } \\
\text { цівників; величина витрат на } \\
\text { оплату праці для створення } 1 \text { грн. } \\
\text { ДВ Л }\end{array}$} & $\begin{array}{l}\mathbf{Y}_{3 \Pi}=\mathbf{3 \Pi}_{Л} / \text { ДВ }_{л}, \\
\text { де } 3 \Pi_{л}-\text { заробітна плата праців- } \\
\text { ників певної ланки ЛЛТР }\end{array}$ \\
\hline & $\begin{array}{l}\text { 3.4. Частка специфіч- } \\
\text { них витрат }\left(\mathbf{Ч}_{\mathbf{C B}}\right)\end{array}$ & \multicolumn{2}{|c|}{$\begin{array}{l}\text { Питома вага специфічних витрат } \\
\text { у ланковій доданій вартості }\end{array}$} & $\begin{array}{l}\mathbf{Y}_{\mathbf{C B}}=\mathbf{B}_{\text {л }} / \text { ДВ } \\
\text { специфічн де } \mathrm{B}_{л}-\text { ланкові витрати. }\end{array}$ \\
\hline & $\begin{array}{l}\text { 3.5. Ланкова структу- } \\
\text { ра ДВ }\end{array}$ & \multicolumn{2}{|c|}{$\begin{array}{l}\text { Частка ланок ланцюга у ринковій } \\
\text { доданій вартості }\end{array}$} & 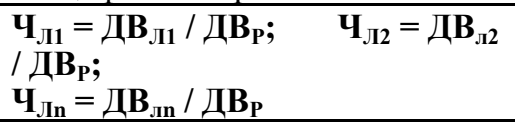 \\
\hline & $\begin{array}{l}\text { 3.6. Ланкова структу- } \\
\text { ра логістичних ви- } \\
\text { трат }\end{array}$ & \multicolumn{2}{|c|}{$\begin{array}{l}\text { Частка ланок ланцюга у загальній } \\
\text { сумі ринкових логістичних ви- } \\
\text { трат }\end{array}$} & 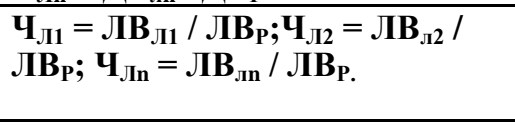 \\
\hline & $\begin{array}{l}\text { 3.7.Ланкова структу- } \\
\text { ра податків }\end{array}$ & \multicolumn{2}{|c|}{$\begin{array}{l}\text { Частка ланок ланцюга у загальній } \\
\text { сумі ринкових податкових над- } \\
\text { ходжень }\end{array}$} & $\begin{array}{l}\mathbf{U}_{\text {Л1 }}=\Pi_{Л 1} / \Pi_{\mathrm{P}} ; \mathbf{U}_{Л 2}=\Pi_{\text {Л2 }} / \Pi_{\mathrm{P}} ; \\
\mathbf{U}_{\text {Лn }}=\Pi_{\text {Лn }} / \Pi_{\mathrm{P}}\end{array}$ \\
\hline
\end{tabular}

розроблено автором із використанням джерел $[5,8]$; ${ }^{* * *}$ індикатор запропоновано автором. 
Перша група індикаторів передбачає діагностику ефективності формування, перерозподілу та структури доданої вартості (далі - ДВ) в ЛЛТР шляхом оцінки динамічних і структурних змін трьох підгруп показників (див. табл. 1). Оскільки цільовим критерієм ефективності ЛЛТР є оптимізація загальної ринкової доданої вартості, оцінка показників іiі формування, перерозподілу та структури постає ключовим блоком діагностики ефективності функціонування ринкового ланцюга. Всі показники, включені до першої групи, через ланцюг причинно-наслідкових зв'язків пов'язані зі стратегічною інтегрованою метою логістичної системи ринку (див. рис. 1).

СЗП представляє собою збалансований комплекс результатів і факторів досягнення цих результатів. Дотримання вимоги зв'язку діагностичних показників із фінансовими результатами суб'єктів ЛЛТР (див. рис. 2) обумовило доцільність включення до складу першої групи індикаторів відтворювальної рентабельності та рентабельності продукції (послуг) у ланковому вимірі (див. табл. 1). Відтворювальна рентабельність визначає обсяг ДВ, що припадає на 1 грн. витрат на виробництво продукції (послуг) певної ланки ринкового ланцюга. Даний індикатор, як правило, перевищує значення традиційного показника рентабельності продукції (послуг). За умови збитковості виробництва та від'ємного значення рентабельності продукції, індикатор відтворювальної рентабельності має позитивне значення, відображаючи величину ланкової ДВ та ефективність використання ресурсів у системі.

Друга підгрупа показників орієнтована на оцінку динаміки логістичних витрат (далі-ЛВ) та їх частки у випуску продукції і ДВ у ланковому й ринковому вимірі (див. табл. 1). Логістичні витрати $€$ одним із головних показників ефективності логістичних систем різних рівнів, вимір яких є доволі складним через недостатність інформаційної бази. Більшість учених визначають сутність ЛВ через виконання різних логістичних операцій. На наш погляд, найбільш універсальним і придатним для ринкових досліджень $є$ визначення дефініції, запропоноване O.M. Сумцем: «витрати на виконання у логістичній системі усіх логістичних активностей, що пов'язані безпосередньо з логістичними потоками в межах визначеного простору й часу» [5, с. 22]. У даному дослідженні компоненти ланкових логістичних витрат визначено за 5 елементами витрат, що корелює з елементами операційних витрат суб'єктів, відображених у р. III агрегованого (за видами економічної діяльності) Звіту про фінансові результати, як інформаційної бази діагностики.

Величина ринкових логістичних витрат визначається як сума ланкових ЛВ. Для оцінки ступеню впливу ЛВ на ефективність функціонування ЛЛТР та обгрунтування шляхів ii підвищення важливим з методологічної точки зору є розрахунок частки ЛВ у загальних витратах суб'єктів складових ланок ланцюга. Даний індикатор варіює за секторами національної економіки (найвищий рівень - до $30 \%$ - притаманний харчовій промисловості, найнижчий - до $10 \%-$ машинобудівній) та державами (у Польщі в 66 \% підприємств індикатор не перевищує $10 \%$, в Україні він може досягати $30 \%$ ) [5, с. 11, 24]. Загалом високий рівень частки ЛВ у загальних витратах та випуску продукції суб'єктів ланок ринкового ланцюга свідчить про наявність резервів підвищення ефективності його функціонування. 3 огляду на відтворювальну природу стратегічної мети ЛЛТР запропоновано новий індикатор, що відображає логістичну складову новоствореної вартості кожної ланки ринкового ланцюга. За величиною частки ЛВ у ланковій доданій вартості можна визначати резерви та способи іiі оптимізації з урахуванням множини чинників.

Третя підгрупа показників орієнтована на оцінку ресурсної структури доданої вартості, визначаючи питому вагу іiі компонентів (прибутку, амортизації необоротних активів, заробітної плати та специфічних витрат) у загальній величині як у ланковому, так і ринковому вимірі (див. табл. 1). Окрім ресурсної, запропоновано діагностувати ланкову структуру ДВ, що відображає частку складових ланок ланцюга у формуванні загальної ринкової доданої вартості. Оцінка ланкової структури ЛВ дозволяє встановити найбільш витратоємні ланки ланцюга, тоді як ланкова структура податків визначає диспропорції у їх ланковому перерозподілі. У цілому перша група СЗП для діагностики ефективності ЛЛТР об'єднала 19 показників, які прямо або опосередковано пов'язані із показником доданої вартості. Інформаційною базою для їх діагностики є дані Державної служби статистики України щодо обсягів та структури витрат на виробництво товарів (послуг) за ланками ринкового ланцюга, внутрішніх цін товарів (послуг), калькуляції собівартості одиниці продукції (послуг), узагальнені дані агрегованого Звіту про фінансові результати, матеріали аналітичних видань.

Друга група індикаторів передбачає діагностику ефективності ресурсовикористання та часових параметрів ЛЛТР шляхом оцінки величин і динаміки змін трьох підгруп показників (таблиця 2). Застосування концепції діаграми збалансованих переваг, що формує концептуальний базис методології діагностики ефективності ЛЛТР, передбачає включення в СЗП індикаторів оборотності запасів та часових параметрів товароруху в ринку (див. рис. 1). Рентабельність капіталу (активів) є додатковим фінансовим показником. Слід зазначити, що у європейській СЗП (balanced scorecard - BSC) на мікрорівні до складу фінансової групи показників включено поряд із економічною доданою вартістю (EVA) рентабельність інвестованого (робочого) капіталу (ROCE) [9].

Підгрупа часових параметрів ринкового ланцюга об'єднала два основних показника: (1) тривалість виробничого (сервісного) циклу певної ланки ЛЛТР, що включає загальний час виробництва, переміщення та зберігання товару в межах ланки; (2) тривалість логістичного циклу ринкового ланцюга, тобто період переміщення матеріального потоку від початкової до кінцевої ланок, як сума тривалості виробничих і сервісних циклів у межах ланцюга певного товарного ринку (див. табл. 2). 
Таблиця 2

Система збалансованих показників для діагностики ефективності ресурсовикористання та часових параметрів ЛЛТР*

\begin{tabular}{|c|c|c|c|}
\hline Підгрупи & Показники & Характеристика & Формула розрахунку \\
\hline \multirow{6}{*}{ 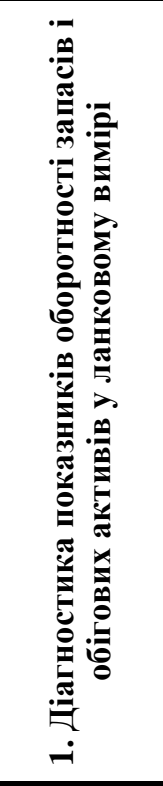 } & $\begin{array}{l}\text { 1.1. Коефіцієнт відво- } \\
\text { лікання обігових ак- } \\
\text { тивів у запаси }\left(\mathbf{K}_{\mathbf{B} 3}\right)\end{array}$ & $\begin{array}{l}\text { Частка запасів у складі обігових } \\
\text { активів певної ланки ЛЛТР }\end{array}$ & $\begin{array}{l}\mathbf{K}_{\mathbf{B} 3}=\mathbf{3}_{\text {Л }} / \mathbf{O A}_{\text {Л}}, \text { де } 3_{\text {Л }}-\text { вартість } \\
\text { запасів; ОА Л - вартість обігових } \\
\text { активів певної ланки. }\end{array}$ \\
\hline & $\begin{array}{l}\text { 1.2. Коефіцієнт обо- } \\
\text { ротності запасів (обо- } \\
\text { роти) }\left(\mathbf{K}_{\mathbf{3}}\right)\end{array}$ & $\begin{array}{l}\text { Кількість оборотів коштів, інвес- } \\
\text { тованих у запаси певної ланки } \\
\text { ЛЛТР }\end{array}$ & $\begin{array}{l}\mathbf{K}_{\mathbf{3}}=\mathbf{C}_{\text {Л }} / \mathbf{3}_{\text {Л}}, \quad \text { де } \mathrm{C}_{л}-\text { собівар- } \\
\text { тість реалізованої продукції у } \\
\text { певній ланці ЛЛТР }\end{array}$ \\
\hline & $\begin{array}{l}\text { 1.3. Період одного } \\
\text { обороту запасів (днів) } \\
\left(\mathbf{T}_{\mathbf{3}}\right)\end{array}$ & $\begin{array}{l}\text { Період, протягом якого запаси } \\
\text { суб'єктів певної ланки ЛЛТР } \\
\text { трансформуються у кошти }\end{array}$ & $T_{3}=360 / K_{3}$ \\
\hline & $\begin{array}{l}\text { 1.4. Коефіцієнт обо- } \\
\text { ротності обігових } \\
\text { активів (обороти) } \\
\left(\mathbf{K}_{\mathbf{0}}\right)\end{array}$ & $\begin{array}{l}\text { Величина чистого доходу на } 1 \\
\text { грн. обігових активів; кількість } \\
\text { оборотів обігових активів за пе- } \\
\text { ріод }\end{array}$ & $\begin{array}{l}\mathbf{K}_{\text {об }}=\mathbf{ч Д л}_{\text {л }} \text { / ОА } \text { л, де ЧД }- \text { чистий } \\
\text { дохід (виручка) від реалізації } \\
\text { продукції у певній ланці ЛЛТР }\end{array}$ \\
\hline & $\begin{array}{l}\text { 1.5. Період одного } \\
\text { обороту обігових ак- } \\
\text { тивів (днів) }\left(\mathbf{T}_{\mathbf{O A}}\right)\end{array}$ & $\begin{array}{l}\text { Середній період від інвестування } \\
\text { коштів у виробництво до отри- } \\
\text { мання виручки від реалізації } \\
\text { продукції }\end{array}$ & $T_{O A}=360 / K_{0 \tilde{\sigma}}$ \\
\hline & $\begin{array}{l}\text { 1.6.Рентабельність } \\
\text { капіталу (активів) } \\
\left(\mathbf{P}_{\mathbf{K}}\right)\end{array}$ & $\begin{array}{l}\text { Величина чистого прибутку на } \\
\text { одиницю інвестованих в активи } \\
\text { коштів за ланками ЛЛТР }\end{array}$ & $\begin{array}{l}\mathbf{P}_{\mathbf{K}}=\mathbf{Ч \Pi}_{Л} / \mathbf{A}_{\boldsymbol{I}} \\
\text { де ЧП Л }- \text { чистий прибуток; } \mathbf{A}_{Л}- \\
\text { вартість активів суб'єктів певної } \\
\text { ланки }\end{array}$ \\
\hline \multirow{3}{*}{ 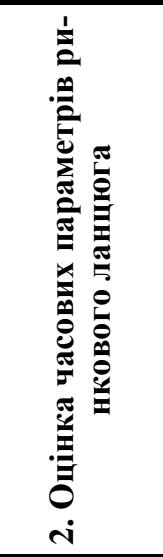 } & $\begin{array}{l}\text { 2.1. Тривалість виро- } \\
\text { бничого циклу ланки } \\
\left.\text { ЛЛТР ( } \mathbf{T}_{\mathbf{B ц}}\right)\end{array}$ & $\begin{array}{l}\text { Загальний час виробництва, пе- } \\
\text { реміщення та зберігання товару у } \\
\text { межах виробничих ланок ЛЛТР }\end{array}$ & 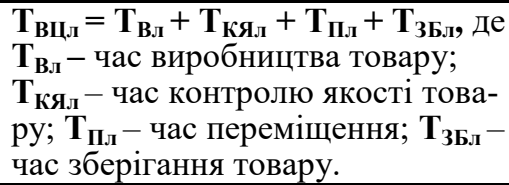 \\
\hline & $\begin{array}{l}\text { 2.2. Тривалість логіс- } \\
\text { тичного циклу ЛЛТР } \\
\left(\mathbf{T}_{\text {лл }}\right)\end{array}$ & $\begin{array}{l}\text { Період переміщення матеріаль- } \\
\text { ного потоку від початкової до } \\
\text { кінцевої ланки ЛЛТР }\end{array}$ & 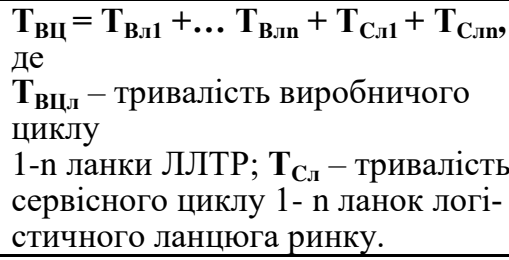 \\
\hline & $\begin{array}{l}\text { 2.3. Ефективність } \\
\text { виробничого циклу } \\
\left(\mathbf{E}_{\mathbf{B L}}\right)[32] \\
\end{array}$ & $\begin{array}{l}\text { Питома вага тривалості виробни- } \\
\text { цтва товару у загальному вироб- } \\
\text { ничому циклі певної ланки ЛЛТР }\end{array}$ & $\mathbf{E}_{\mathrm{BL}}=\mathbf{T}_{\mathrm{B}} / \mathbf{T}_{\mathrm{BL}} \quad(<\mathbf{1})$ \\
\hline \multirow{3}{*}{ 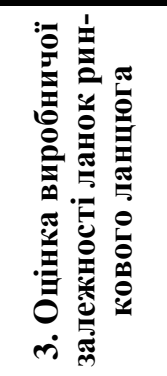 } & $\begin{array}{l}\text { 3.1. Ланкова матеріа- } \\
\text { ловіддача }\left(\mathbf{M B}_{\text {J }}\right)^{* * *}\end{array}$ & $\begin{array}{l}\text { Автономія праці; величина ДВ, } \\
\text { що припадає на } 1 \text { грн. уречевле- } \\
\text { ної праці }\end{array}$ & $\begin{array}{l}\mathbf{M B}_{\text {л }}=Д \mathbf{B}_{\text {л }} / \mathbf{M B}_{\text {л }} \text { де } \\
\text { МВ }_{\text {л }} \text { - вартість матеріальних ви- } \\
\text { трат у ланках ЛЛТР }\end{array}$ \\
\hline & $\begin{array}{l}\text { 3.2. Ланкова матеріа- } \\
\text { ломісткість }\left(\mathbf{M}_{\mathbf{M}}\right)\end{array}$ & $\begin{array}{l}\text { Залежність виробничого процесу } \\
\text { від зовнішніх джерел; розмір пе- } \\
\text { ренесеної вартості для продуку- } \\
\text { вання } 1 \text { грн. ДВ }\end{array}$ & $\mathbf{M M}_{л}=\mathbf{M B}_{\pi} /$ ДВ \\
\hline & $\begin{array}{l}\text { 3.3.Ланкова продук- } \\
\text { тивність праці } \\
\left(\boldsymbol{\Pi П}_{Л}\right)^{* *}\end{array}$ & $\begin{array}{l}\text { Величина вартості, що створю- } \\
\text { ється в процесі виробництва } 1 \\
\text { працівником }\end{array}$ & $\begin{array}{l}\text { ППл }=\text { ДВ } / \mathbf{Ч}_{л}, \quad \text { де } \mathrm{Ч}_{Л}-\text { чисе- } \\
\text { льність Працівників у ланках ри- } \\
\text { нкового ланцюга }\end{array}$ \\
\hline
\end{tabular}

розроблено автором із використанням джерел $[5,8,9,10] ;{ }^{* * *}$ індикатор запропоновано автором.

У системі показників BSC менеджери часто розраховують ефективність виробничого циклу (manufacturing cycle effectiveness - MCE) як питому вагу тривалості виробництва товару у виробничому циклі певної ланки ланцюга [9]. Даний індикатор може застосовуватися і для ЛЛТР за умови наявності достатньої інформації про часові цикли складових ланок ланцюгів.

Підгрупа індикаторів виробничої залежності та продуктивності праці, що розраховуються для складових ланок ЛЛТР, сконструйована на базі пока- зника ланкової доданої вартості (замість виручки від реалізації продукції), забезпечуючи таким чином взаємозв'язок зі стратегічною метою ЛЛТР (див. табл. 2). У цілому друга група СЗП для діагностики ефективності ЛЛТР об'єднала 12 показників, які, в основному, опосередковано пов'язані із критерієм доданої вартості. Інформаційною базою для їх діагностики є узагальнені дані агрегованого (за видами економічної діяльності) Балансу та Звіту про фінансові результати, калькуляції собівартості товарів (послуг), аналітичні матеріали. 
Спільною рисою діагностики показників першої і другої груп СЗП (див. табл. 1, 2) є здійснення порівняльної оцінки фактичних значень індикаторів із їх величинами попередніх періодів, використання в ході розширеної інтерпретації отриманих результатів базових і ланцюгових індексів. В ході діагностики показників третьої та четвертої груп СЗП, окрім оцінки динамічних змін індикаторів у часі, передбачено їх порівняльний аналіз із ичільовими або нормативними рівнями, застосування способів і методів якісної оцінки. Компоненти (підгрупи), їх характеристики та цільові значення наступних трьох груп показників узагальнено в табл.3.

Таблиця 3

Система збалансованих показників для діагностики потужності руху матеріальних потоків, тенденцій сталого розвитку та якості логістичного обслуговування в ЛЛТР*

\begin{tabular}{|c|c|c|c|}
\hline Підгрупи & Показники & Характеристика & $\begin{array}{c}\text { Оціночна шкала, цільові } \\
\text { значення }\end{array}$ \\
\hline 1 & 2 & 3 & 4 \\
\hline \multicolumn{4}{|c|}{ Група 3. Діагностика потужності руху внутрішніх і зовнішніх матеріальних потоків у ЛЛТР } \\
\hline \multirow{5}{*}{ 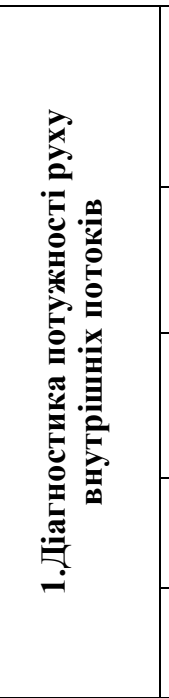 } & $\begin{array}{l}\text { 1.1.Потужність руху } \\
\text { внутрішніх матеріа- } \\
\text { лопотоків у ЛЛТР }^{* *} \\
\left(\mathbf{\Pi}_{\mathbf{B H}}\right)\end{array}$ & $\begin{array}{l}\text { Співвідношення обсягів внутріш- } \\
\text { нього споживання товару до обсягів } \\
\text { його виробництва у розрізі виробни- } \\
\text { чих ланок ЛЛТР(у \%) }\end{array}$ & $\begin{array}{l}\text { Якісно-кількісна оиінка: } \\
\text { 1. Низька (менше } 30 \%) \\
\text { 2. Середня }(30-60 \%) \\
\text { 3. Висока }(60-90 \%) \\
\text { 4. Дуже висока (більше } 90 \%) .\end{array}$ \\
\hline & $\begin{array}{l}\text { 1.2. Індекс виробниц- } \\
\text { тва товарів у ланках } \\
\text { ЛЛТР }\left(\mathbf{I}_{\mathbf{B}}\right)\end{array}$ & $\begin{array}{l}\text { Відношення обсягів фактично виро- } \\
\text { блених товарів у ланках ЛЛТР за } \\
\text { звітний період до аналогічного пока- } \\
\text { зника попереднього періоду }\end{array}$ & $\begin{array}{l}\text { Збільшення в динаміці за умов } \\
\text { зростаючого попиту на товари; } \\
\text { > Індексу імпорту товарів }\end{array}$ \\
\hline & 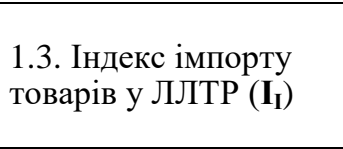 & $\begin{array}{l}\text { Відношення обсягів імпортованих } \\
\text { товарів у ЛЛТР за звітний період до } \\
\text { аналогічного показника попередньо- } \\
\text { го періоду }\end{array}$ & $\begin{array}{l}\text { Зменшення у динаміці за умов } \\
\text { наявності внутрішнього вироб- } \\
\text { ництва в державі та нарощу- } \\
\text { вання його обсягів }\end{array}$ \\
\hline & $\begin{array}{l}\text { 1.4.Коефіцієнт дис- } \\
\text { кримінаційності вну- } \\
\text { трішніх цін }^{* *}\left(\mathbf{K}_{\text {Цвн. }}\right)\end{array}$ & $\begin{array}{l}\text { Співвідношення рівня імпортних цін } \\
\text { певного товару до рівня внутрішніх } \\
\text { цін за певний часовий період }\end{array}$ & Зменшення у динаміці \\
\hline & $\begin{array}{l}\text { 1.5. Індекс внутріш- } \\
\text { ніх цін }\left(\mathbf{I}_{\text {Цвн }}\right)\end{array}$ & $\begin{array}{l}\text { Відношення внутрішніх цін товарів } \\
\text { звітного періоду до аналогічного } \\
\text { показника попереднього періоду }\end{array}$ & $\begin{array}{l}\leq \text { Індексу доходів споживачів } \\
\text { товарів }\end{array}$ \\
\hline \multirow{4}{*}{ 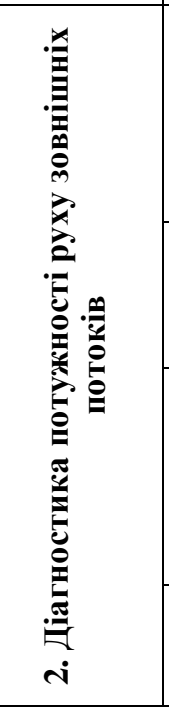 } & 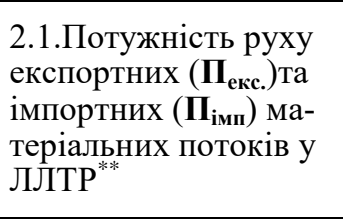 & $\begin{array}{l}\text { Співвідношення обсягів експор- } \\
\text { ту/імпорту товару до обсягів його } \\
\text { виробництва у розрізі виробничих } \\
\text { ланок ЛЛТР (у \%) }\end{array}$ & $\begin{array}{l}\text { Якісно-кількісна оцінка: } \\
\text { 1. Дуже низька (менше } 10 \%) \\
\text { 2. Низька (10-20\%) } \\
\text { 3. Середня (20-30\%) } \\
\text { 4. Висока (30-40\%) } \\
\text { 5. Дуже висока (більше } 40 \%) \text {. }\end{array}$ \\
\hline & 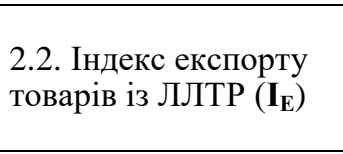 & $\begin{array}{l}\text { Відношення обсягів експортованих } \\
\text { товарів за звітний період до аналогі- } \\
\text { чного показника попереднього пері- } \\
\text { оду }\end{array}$ & $\begin{array}{l}\geq \text { Індексу імпорту товарів в } \\
\text { ЛЛТР }\end{array}$ \\
\hline & $\begin{array}{l}\text { 2.3. Частка імпорту в } \\
\text { товарообороті ланки } \\
\text { реалізації продукції } \\
\left(\mathbf{Ч}_{\mathbf{T}}\right)[11]\end{array}$ & $\begin{array}{l}\text { Частка продажу імпортних продово- } \\
\text { льчих товарів через торговельну ме- } \\
\text { режу вітчизняних підприємств (\%) }\end{array}$ & $\begin{array}{l}\text { Для продовольчих товарів [11]: } \\
\text { 1.25\% - критичний рівень } \\
\text { 2. } 23 \% \text { - небезпечний. } \\
\text { 3. } 20 \% \text { - незадовільний рівень. } \\
\text { 4. } 16 \% \text { - задовільний рівень. } \\
\text { 5. } 12 \% \text { - оптимальний рівень. }\end{array}$ \\
\hline & 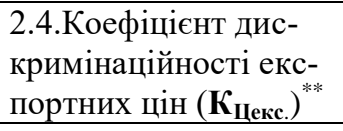 & $\begin{array}{l}\text { Співвідношення рівня імпортних цін } \\
\text { певного товару до рівня експортних } \\
\text { цін за певний часовий період }\end{array}$ & Зменшення у динаміці; $\leq 1$ \\
\hline \multicolumn{4}{|c|}{ Група 4. Діагностика тенденцій сталого розвитку ЛЛТР } \\
\hline \multirow{2}{*}{ 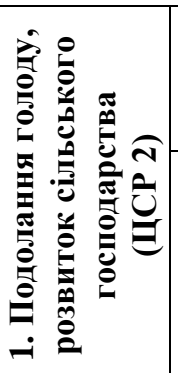 } & $\begin{array}{l}\text { 1.1. Індекс аграрної } \\
\text { продукції }[12, \text { с.20]. }\end{array}$ & $\begin{array}{l}\text { Відношення обсягів виробництва } \\
\text { аграрної продукції звітного періоду } \\
\text { до аналогічного показника базового } \\
\text { періоду (2005p.) }\end{array}$ & $\begin{array}{l}\text { Порівняння з цільовим значен- } \\
\text { ням індикатора } 2025 \text { р. [12, } \\
\text { c.21]. }\end{array}$ \\
\hline & $\begin{array}{l}\text { 1.2. Суб’єктна струк- } \\
\text { тура виробництва } \\
\text { агропродукції }\end{array}$ & $\begin{array}{l}\text { Структура виробництва агропродук- } \\
\text { ції у розрізі корпоративного та інди- } \\
\text { відуального секторів (сировинна } \\
\text { ланка ЛЛТР) }\end{array}$ & $\begin{array}{l}\text { Оцінка динаміки структурних } \\
\text { змін }\end{array}$ \\
\hline
\end{tabular}


Продовження табл. 3

\begin{tabular}{|c|c|c|c|c|}
\hline Підгрупи & Показники & Характеристика & \multicolumn{2}{|c|}{$\begin{array}{l}\text { Оціночна шкала, цільові } \\
\text { значення }\end{array}$} \\
\hline 1 & 2 & 3 & \multicolumn{2}{|c|}{4} \\
\hline & $\begin{array}{l}\text { 1.3. Рівні цін агроп- } \\
\text { родукції за катего- } \\
\text { ріями виробників }\end{array}$ & $\begin{array}{l}\text { Рівні цін агропродукції у розрізі ко- } \\
\text { рпоративного та індивідуального } \\
\text { секторів (сировинна ланка ЛЛТР) }\end{array}$ & \multicolumn{2}{|c|}{$\begin{array}{l}\text { Співвідношення рівнів цін в } \\
\text { індивідуальному та корпорати- } \\
\text { вному секторах сировинної } \\
\text { ланки ЛЛТР }\end{array}$} \\
\hline & $\begin{array}{l}\text { 1.4. Індекс виробни- } \\
\text { цтва харчових про- } \\
\text { дуктів, \% } \\
{[12, \text { с. } 20] .}\end{array}$ & $\begin{array}{l}\text { Відношення обсягів виробництва } \\
\text { харчових продуктів звітного періоду } \\
\text { до аналогічного показника базового } \\
\text { періоду }(2005 \text { p.) }\end{array}$ & \multicolumn{2}{|c|}{$\begin{array}{l}\text { Порівняння з цільовим значен- } \\
\text { ням індикатора } 2025 \text { р. [12, } \\
\text { с.21]. } \\
\text { Порівняння з базовим індексом } \\
\text { аграрної продукції }\end{array}$} \\
\hline & $\begin{array}{l}\text { 1.5. Частка перероб- } \\
\text { ної продукції в аг- } \\
\text { рарному експорті, \% } \\
{[12, \text { с.20]. }}\end{array}$ & $\begin{array}{l}\text { Частка продукції харчової промис- } \\
\text { ловості та переробки аграрної сиро- } \\
\text { вини в експорті груп 1-24 УКТЗЕД, } \\
\%\end{array}$ & \multicolumn{2}{|c|}{$\begin{array}{l}\text { Порівняння з цільовим значен- } \\
\text { ням індикатора } 2025 \text { р. [12, } \\
\text { с.21]. }\end{array}$} \\
\hline & $\begin{array}{l}\text { 1.6. Індекс спожив- } \\
\text { чих цін }[12, \text { с. } 20] .\end{array}$ & $\begin{array}{l}\text { Індекс споживчих цін на продукти } \\
\text { харчування (середньорічний) за ос- } \\
\text { новними групами продуктів, \% }\end{array}$ & \multicolumn{2}{|c|}{$\begin{array}{l}\text { Порівняння з цільовим значен- } \\
\text { ням індикатора } 2025 \text { р. [12, } \\
\text { c. } 21] \text {. }\end{array}$} \\
\hline 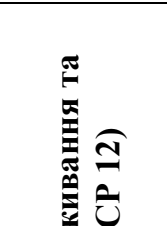 & $\begin{array}{l}\text { 2.1. Частка післяз- } \\
\text { биральних втрат у } \\
\text { виробництві куль- } \\
\text { тур, \% [12, с.92]. }\end{array}$ & $\begin{array}{l}\text { Частка післязбиральних втрат (\%) у } \\
\text { загальному виробництві: } \\
\text { - зернових культур; } \\
\text { - овочів та баштанних культур; } \\
\text { - плодово-ягідних культур }{ }^{* *} \text {. }\end{array}$ & \multicolumn{2}{|c|}{$\begin{array}{l}\text { Порівняння з цільовим значен- } \\
\text { ням індикатора } 2025 \text { р. [12, } \\
\text { с.93]. } \\
\text { Оцінка динамічних змін інди- } \\
\text { каторів }\end{array}$} \\
\hline 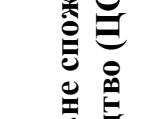 & $\begin{array}{l}\text { 2.2. Індекс утворе- } \\
\text { них відходів в ЛЛТР }\end{array}$ & $\begin{array}{l}\text { Базисний індекс обсягів утворених } \\
\text { відходів в ланковому та ринковому } \\
\text { вимірі }\end{array}$ & \multicolumn{2}{|c|}{$\begin{array}{l}\text { Оцінка динаміки змін, порів- } \\
\text { няння із секторальними індика- } \\
\text { торами }\end{array}$} \\
\hline 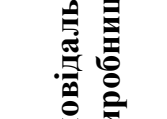 & $\begin{array}{l}\text { 2.3. Індекс спалених } \\
\text { і утилізованих від- } \\
\text { ходів в ЛЛТР }\end{array}$ & $\begin{array}{l}\text { Базисний індекс обсягів спалених і } \\
\text { утилізованих відходів в ланковому } \\
\text { та ринковому вимірі }\end{array}$ & \multicolumn{2}{|c|}{$\begin{array}{l}\text { Оцінка динаміки змін, порів- } \\
\text { няння із секторальними індика- } \\
\text { торами }\end{array}$} \\
\hline i & $\begin{array}{l}\text { 2.4. Частка спалених } \\
\text { і утилізованих від- } \\
\text { ходів в ЛЛТР }\end{array}$ & $\begin{array}{l}\text { Частка спалених й утилізованих від- } \\
\text { ходів в загальному обсязі утворених } \\
\text { відходів в ланковому й ринковому } \\
\text { вимірі }\end{array}$ & \multicolumn{2}{|c|}{$\begin{array}{l}\text { Порівняння з цільовим значен- } \\
\text { ням індикатора } 2025 \text { р. [12, } \\
\text { c.93]. }\end{array}$} \\
\hline \multicolumn{5}{|c|}{ Група 5. Діагностика якості логістичного обслуговування в ЛЛТР } \\
\hline \multirow{7}{*}{ 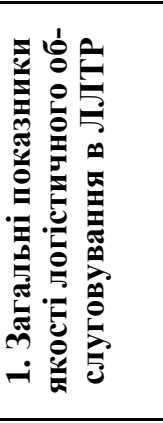 } & \multicolumn{3}{|c|}{$\begin{array}{l}\text { 1.1.Рівень задоволення внутрішнього (промислового й споживчого) попи- } \\
\text { ту в державі }\end{array}$} & \multirow{7}{*}{$\begin{array}{l}\text { Якісно-кількісна } \\
\text { оцінка }[13] \text { : } \\
1 . \text { Дуже низька } \\
(0-0,20) \\
2 . \text { Низька } \\
(0,21-0,35)\end{array}$} \\
\hline & \multicolumn{3}{|c|}{ 1.2. Гнучкість ЛЛТР (здатність реагувати на зовнішні впливи) } & \\
\hline & \multicolumn{3}{|c|}{$\begin{array}{l}\text { 1.3. Надійність логістичного обслуговування в ЛЛТР (виконання договір- } \\
\text { них зобов'язань) }\end{array}$} & \\
\hline & \multicolumn{3}{|c|}{ 1.4. Безперебійність постачань сировини й товару } & \\
\hline & \multicolumn{3}{|c|}{ 1.5. Ступінь задоволення споживачів за часовими параметрами } & \\
\hline & \multicolumn{3}{|c|}{ 1.6. Корисність логістичного обслуговування в ЛЛТР } & \\
\hline & \multicolumn{3}{|c|}{ 1.7. Рівень використання інноваційних логістичних технологій ${ }^{* *}$} & \\
\hline \multirow[b]{2}{*}{ 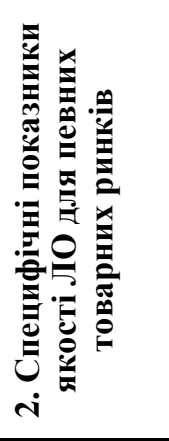 } & \multicolumn{3}{|c|}{$\begin{array}{l}\text { Визначаються особливостями процесів відтворення й товароруху певних } \\
\text { ринків }\end{array}$} & 3. Середня \\
\hline & \multicolumn{3}{|c|}{$\begin{array}{l}\text { Приклади: } \\
\text { 2.1. Для ринку зерна (промислове споживання): } \\
\text { - достатність запасів зерна для внутрішнього споживання }{ }^{* *} ; \\
\text { - доступність елеваторних послу для зерновиробників }{ }^{* *} ; \\
\text { - співвідношення якість/ціна послуг зернових складів }{ }^{* *} \text {. } \\
\text { 2.2. Для ринку хліба та хлібобулочних виробів (кінцеве споживання насе- } \\
\text { ленням): } \\
\text { - асортиментна диференціація товарів }{ }^{* *} ; \\
\text { - співвідношення якість/ціна продукції }{ }^{* *} ; \\
\text { - якість торгівельного обслуговування споживачів. }\end{array}$} & $\begin{array}{l}\text { 4. Висока } \\
(0,66-0,80) \\
\text { 5. Дуже висока } \\
(0,81-1,00)\end{array}$ \\
\hline
\end{tabular}

розроблено із використанням джерел $[4,8,11,12,13]$; $\quad$ індикатор запропоновано автором.

Група показників діагностики потужності руху внутрішніх і зовнішніх матеріальних потоків у ланцюгах має виключно ринкову спрямованість і не розраховується у мікрологістичних системах. Доціль- 
ність її конструювання та інтеграції в СЗБ для діагностики ефективності ЛЛТР обумовлена, з одного боку, необхідністю постійного моніторингу фізичних обсягів і цінових співвідношень імпортних і вітчизняних товарів для забезпечення національної економічної безпеки, з іншого, значним впливом індикаторів даної групи на стратегічну мету й головний критерій ефективності ланцюгів ринку - оптимізацію загальної доданої вартості.

Потужність руху внутрішніх матеріалопотоків у ринкових ланцюгах запропоновано розраховувати як співвідношення обсягів внутрішнього споживання товарів до обсягів їх виробництва у розрізі ресурсоутворюючих (сировинних і виробничих) ланок ЛЛТР (див. табл. 3). Для діагностики потужності міжланкового руху матеріальних потоків у ринковому ланцюгу передбачено використати подвійну оціночну шкалу (якісну та кількісну) для внутрішніх i зовнішніх потоків окремо. Конструювання кількісної оціночної шкали здійснювалося автором 3 позиції відповідності напрямів і обсягів товароруху в ринкових ланцюгах державним економічним інтересам, тому вона $є$ різною для внутрішніх і зовнішніх потоків. Потужність товароруху внутрішніх потоків може бути чотирьох видів: (1) низька (менше $30 \%$ ); (2) середня (30-60\%); (3) висока (60-90\%); (4) дуже висока (більше $90 \%)$.

Потужність руху зовнішніх матеріалопотоків у ринкових ланцюгах запропоновано розраховувати як співвідношення обсягів експорту (імпорту) товарів до обсягів їх виробництва у розрізі ресурсоутворюючих ланок ЛЛТР (див. табл. 5). Для оцінки потужності руху зовнішніх товаропотоків передбачено використати п'ятиелементну шкалу із кроком в $10 \%$ : (1) дуже низька - менше $10 \%$; (2) низька - 10-20\%; (3) середня - 20-30\%; (4) висока - 30-40\%; (5) дуже висока - більше $40 \%$. Максимальний рівень потужності обмежений критерієм в $40 \%$, що корелює 3 граничним значенням ступеня відкритості ринку (СВР) щодо міжнародної торгівлі. Відповідно до Методики №49-р від 05.03.2002 р. [14, с. 253], перевищення СВР $40 \%$-го рівня є ознакою відкритості державного ринку і його залежності від кон'юнктури світового ринку. Слід зазначити, що впровадження державних економічних інтересів у ЛЛТР може відбуватися за певного оптимального співвідношення потужності руху внутрішніх і зовнішніх товарних потоків, при цьому таке співвідношення повинне бути різним для сировинних і переробних типів ринків [8].

Окрім базового індикатора потужності руху внутрішніх потоків у ЛЛТР, до складу першої підгрупи включено низку додаткових показників (див. табл. 3). Зокрема, для оцінки збалансованості матеріальних і фінансових потоків в ЛЛТР, втрат доданої вартості в ринку запропоновано розрахунок коефіuієнтів дискримінаційності внутрішніх і експортних цін, як співвідношення величин імпортних цін певних товарів до рівня їх внутрішніх і експортних цін відповідно за певний часовий період.

До складу другої підгрупи в якості додаткових діагностичних індикаторів віднесено ланцюгові індекси експорту товарів (для їх порівняння з аналогічним показником імпорту товарів) і частку імпорту в товарообороті збутової ланки логістичного ланцюга (див. табл. 3). Останній є одним із індикаторів продовольчої безпеки держави відповідно до чинних Методичних рекомендацій [11], який визначає частку продажу імпортних продовольчих товарів через торговельну мережу вітчизняних підприємств. У СЗП даний індикатор виконує подвійну функцію: (1) локально (у межах однієї збутової ланки) характеризує потужність руху зовнішніх товаропотоків у ринкових ланцюгах; (2) оцінює стан продовольчої безпеки України та іiі регіонів.

У цілому третя група СЗП для діагностики ефективності ЛЛТР об'єднала 9 показників, які через ланцюг причинно-наслідкових зв'язків пов'язані із показником ринкової доданої вартості. Базуючись на відтворювальному та регуляторному підході, дана група показників орієнтована на встановлення структурних диспропорцій у потужності руху внутрішніх і зовнішніх матеріальних потоків у ЛЛТР, цінових дисбалансів у певних ланках і ринкових ланцюгах в цілому, погроз економічній, у тому складі продовольчій безпеці держави. Інформаційною базою для їх діагностики $є$ дані Державної служби статистики України щодо балансів виробництва і споживання, обсягів експорту та імпорту певних товарів, а також їх цін (внутрішніх, експортних і імпортних), матеріали аналітичних видань.

Інтеграція групи показників оцінки тендениій сталого розвитку в СЗП для діагностики ефективності ЛЛТР обумовлена, з одного боку, актуалізацією моніторингу впровадження Цілей сталого розвитку (далі - ЦСР) в національну економіку, з іншого, необхідністю формування соціо- й екологоорієнтованих ринкових ланцюгів у відповідності до вимог концепцій сталого розвитку та інклюзивного зростання. На підставі проведеного аналізу сутності завдань ЦСР і їх індикаторів запропоновано включити в СЗП низку показників, що мають логістичний вимір, у розрізі 2-і «Подолання голоду, розвиток сільського господарства» та 12-ї ЦСР «Відповідальне споживання та виробництво» (див. табл. 3).

До складу першої підгрупи показників для діагностики тенденцій сталого розвитку інтегровано низку індикаторів для моніторингу стану виконання 2, 3 і 4 завдань другої ЦСР, адаптованих для України [12]. На нашу думку, вони доповнюють діагностику потужності руху матеріальних потоків і цінових співвідношень у логістичних ланцюгах агропродовольчих ринків. Ці індикатори дозволяють визначити потужність матеріальних потоків у сировинній і переробній ланках ЛЛТР, рівень цінової волатильності цін і їх вплив на розвиток споживчої ланки.

Ринково-логістичний вимір другої ЦСР «Подолання голоду, розвиток сільського господарства» притаманний 3-му завданню, що акцентує увагу на забезпеченні гарантованого та рівного доступу дрібних виробників продовольства до виробничих ресурсів, ринків і можливостей для збільшення доданої вартості та зайнятості в несільськогосподарських 
секторах (глобальне визначення) [15]. У ході адаптації даного завдання відбулося його скорочення; в Національній доповіді зазначено, що передбачається аналіз за повним визначенням [12, с.149]. Однак у національній системі моніторингу відсутні індикатори, що характеризують рівень доступу малих товаровиробників до ринків $[12$, с.20], обумовлюючи об'єктивну необхідність їх конструювання.

Враховуючи наявну в Україні статистичну базу, пропонуємо розраховувати суб'єктну структуру виробництва певних видів агропродукції у розрізі корпоративного та індивідуального секторів (об'єднує фермерські й особисті селянські господарства) ринку (див. табл. 3). Такі показники дозволять встановити особливості перерозподілу товарних ніш між великими та малими товаровиробниками та динаміку структурних змін. 3 огляду на відсутність статистичних даних про рівні рентабельності особистих селянських господарств (фізичних осіб), оцінку їх доходності можна здійснити за рівнями цін агропродукції різних категорій виробників. Діагностика співвідношення цін суб'єктів індивідуального й корпоративного секторів дозволить визначити домінуючий напрям перерозподілу доданої вартості в ринковому агропродовольчому ланцюгу. Відтак, запропоновані індикатори орієнтовані на оцінку доступу індивідуальних товаровиробників до різних ланок ЛЛТР та рівня їх доходності і відтворювальної спроможності, поглиблено характеризуючи впровадження третього завдання 2-ї ЦСР у вітчизняну практику господарювання.

Друга підгрупа показників об'єднала низку індикаторів для діагностики стану впровадження 2 і 4 завдань 12-ї ЦСР «Відповідальне споживання та виробництво» у ринково-логістичному вимірі (див. табл. 3). Перший індикатор визначає стан виконання другого завдання ЦСР, орієнтованого на зменшення втрат продовольства у виробничо-збутових ланцюжках [12, с. 92], відтак, має логістичну природу. Наступні три індикатори другої підгрупи орієнтовані на моніторинг впровадження четвертого завдання 12-ї ЦСР щодо зменшення обсягу утворених відходів і збільшення величини їх переробки та повторного використання на основі інноваційних технологій та виробництв [12, с. 92].

Загалом четверта група СЗП для діагностики ефективності ЛЛТР об'єднала 10 показників, які через ланцюг причинно-наслідкових зв'язків пов'язані зі стратегічною інтегрованою метою ринкового ланцюга (див. рис. 1). Базуючись на концепції сталого розвитку, дана група індикаторів орієнтована, з одного боку, на моніторинг впровадження завдань 2-ї та 12-ї ЦСР у вітчизняну практику, з іншого, на оцінку потужності матеріальних потоків окремих ланок, втрат ресурсів у ЛЛТР та стану ланки поводження 3 відходами у ринковому вимірі. Інформаційною базою для їх діагностики є дані Державної служби статистики України щодо балансів продовольчих ресурсів у державному й регіональному вимірі, обсягів виробництва й експорту товарів, рівнів споживчих цін, утворення відходів та поводження 3 ними. Слід за- значити можливість розширення четвертої групи показників у випадку введення нових форм статистичної звітності щодо сталого розвитку підприємств.

У діючих методиках за рівнем значимості показники для оцінки якості логістичного обслуговування посідають третє місце після рівня логістичних витрат та часових параметрів логістичного циклу. У пропонованій СЗБ для діагностики ефективності ЛЛТР вони формують останню 5-ту групу показників для діагностики якості логістичного обслуговування ринкових ланцюгів (див. табл. 3). До складу п'ятої групи діагностичних показників включено дві підгрупи: загальні показники якості логістичного обслуговування, притаманні будь-яким типам ринків, і сneцифічні параметри, склад яких визначається особливостями процесів відтворення й товароруху певного товарного ринку.

Грунтуючись на базових характеристиках ланцюгів товарних ринків, до складу підгрупи загальних показників якості логістичного обслуговування віднесено 7 параметрів (див. табл. 3). Найголовнішими 3 них $є$ рівень задоволення внутрішнього попиту в державі (оцінює збалансованість кількісно-якісних параметрів попиту й пропозиції певних видів товарів), гнучкість ЛЛТР, тобто їх здатність оперативно реагувати на зміни у зовнішньому турбулентному середовищі, та надійність логістичного обслуговування, що визначає здатність суб'єктів матеріалопровідного ланцюга ринку виконати в належний термін договірні зобов'язання перед промисловими споживачами й населенням. 3 огляду на вагому роль інновацій у формуванні логістичних стратегій [1], в оцінці бізнес- процесів (виявлення поточних i майбутніх потреб споживачів і способів їх задоволення) за методикою BSC [9], до складу першої підгрупи інтегровано показник рівня використання інноваційних логістичних технологій в певному ринку, зокрема, «холодної» логістики, нових способів зберігання товарів тощо.

Друга підгрупа об'єднала низку специфічних показників якості обслуговування, які диференціюються як за сегментами споживання (промислове й кінцеве), так і специфікою процесів відтворення й логістики певних товарних ринків (див. табл. 3). Як приклад, для ринку зерна до складу специфічних показників включено достатність запасів зерна для внутрішнього споживання, доступність елеваторних послуг для виробників, співвідношення якість/ціна послуг зернових складів. Для ринку товарів кінцевого споживання, зокрема, хліба та хлібобулочних виробів, специфічні показники оцінюють, передусім, потенційні очікування населення, та включають, зокрема, асортимент товарів, співвідношення якість/ціна продукції, якість торгівельного обслуговування.

Діагностика якості логістичного обслуговування в ЛЛТР передбачає три етапи: (1) формування комплексу загальних і специфічних показників у відповідності із цільовими орієнтирами логістичної системи; (2) обгрунтування відносної значимості кожного показника 3 урахуванням сучасних логістичних тенденцій певного товарного ринку; (3) розрахунок 
узагальненого індикатора якості логістичних послуг. На думку учених, на всіх етапах діагностики якості логістичного обслуговування доцільно застосовувати метод експертних оцінок. Для якісної оцінки як одиничних показників, так і узагальненого індикатора логістичних послуг в ринкових ланцюгах запропоновано використати класичну шкалу якості Харрінгтона [13]. За такого способу нормування показники якості логістичних послуг набувають значення від 0 до 1 . Чим вони є ближчими до 1, тим вища якість логістичного обслуговування в ланцюгу певного товарного ринку, і навпаки.

3 метою підвищення достовірності результатів експертної оцінки важливим завданням є адаптація базових анкет для різних груп експертів - фахівців товарних ринків, маркетологів і логістів, керівниін. Доцільно передбачити можливість доповнення експертами системи загальних і специфічних показників (див. табл. 3), а також проведення процедури їх ранжування із визначенням коефіцієнтів вагомості для кожного показника. Це забезпечить динамічність, об'єктивність отриманих експертним шляхом результатів.

Користувачами методичних положень діагностики ефективності функціонування ЛЛТР можуть бути як державні й регіональні органи влади, так і ринкові суб'єкти та їх профільні інституції, а також різні стейкхолдери, що прямо або опосередковано зацікавлені у розширеному відтворенні товароруху та подоланні логістичних «розривів» в ланцюгах певних товарних ринків. Результати діагностики ефективності функціонування логістичних ланцюгів товарних ринків, здійсненої на основі авторських методичних положень, формують аналітичне підгрунтя для встановлення причинно-наслідкових зв'язків між діагностичними показниками, аналізу міжланкових балансів головних індикаторів ефективності ЛЛТР, формулювання агрегованого висновку про сучасний стан i проблеми логістики певних товарних ринків.

Висновки та перспективи подальших досліджень. Підсумовуючи вищевикладене, відзначимо переваги розроблених методичних положень діагностики ефективності функціонування ЛЛТР:

1) багаторівнева оцінка динаміки і структури доданої вартості та логістичних витрат суб'єктів ринкових ланцюгів, напрямів міжланкового перерозподілу доданої вартості в матеріалопровідному ланцюгу; ків і працівників підприємств, кінцевих споживачів та гнучкість і різноаспектність процедури анкетування,

2) проведення порівняльного аналізу головних індикаторів ефективності між різними ланками ринкового ланцюга (на основі міжланкових балансів), що дозволяє встановити глибинні «розриви» потокових процесів та базові ланки ланцюга, які є об'єктом управлінського впливу;

3) оцінка пропорційності розвитку ринкового ланцюга шляхом розрахунку показників структури в статиці й динаміці для визначення структурних дисбалансів, що гальмують його розвиток;

4) оцінка в логістичному вимірі сучасних тенденцій ринкової економіки, зокрема, зовнішньоекономічної діяльності, тенденцій сталого розвитку в ринковому аспекті, відтворювальних процесів у ланцюгах;

5) цільова орієнтованість сконструйованої СЗП на досягнення стратегічної інтегрованої мети ЛЛТР та пов'язаність включених до системи індикаторів через ланцюг причинно-наслідкових зв'язків із головним критерієм ефективності ланцюгів - оптимізація загальної ринкової доданої вартості;

6) висока регуляторна здатність діагностичних показників, можливість їх використання в якості наукового обгрунтування управлінських рішень;

7) гнучкість методичних положень, їх висока адаптивність до нових умов дослідження, зокрема, зміни завдань, розширення інформаційної бази, врахування специфіки процесів відтворення певних товарних ринків тощо.

Наукова новизна проведеного дослідження полягає в удосконаленні теоретико-методологічних засад ринкової логістики в частині розробки методичного забезпечення для діагностики ефективності ЛЛТР на базі синтезу чотирьох наукових підходів (відтворювального, регуляторного, концепцій діаграми збалансованих переваг і сталого розвитку). Прикладна значимість запропонованого методичного забезпечення визначається можливістю його використання ринковими суб'єктами в ході діагностики ефективності логістичної діяльності, розробки логістичних стратегій, а також органами влади різних рівнів в ході обгрунтування базових ланок і логістичних «розривів» в ЛЛТР, адаптивних механізмів і заходів їх регулювання, оцінки ефективності управлінського впливу у площині реалізації економічних інтересів ринкових суб'єктів та держави, моніторингу стану національної економічної безпеки, розробки програм і стратегій відтворювального розвитку товарних ринків.

\section{Література}

1. Witkowski J. Metodologiczne podstawy strategii logistycznej w rzedsiębiorstwie. GmiL. 1993. № 12. S. 214-217.

2. Кочубей Д. Оцінка ефективності функціонування логістичної системи торговельних підприємств // Вісник Київського національного торговельно-економічного університету. 2009. №4. С. 59-66.

3. Сумець О.М. Сучасні підходи до визначення ефективності логістичної діяльності підприємства та ії оцінювання //Логистика: проблемы и решения. 2019. №6 (85). С.32-42.

4. Сумець О.М. Оцінка рівня логістичного обслуговування споживачів продукції виробничих підприємств // Вісник ХНТУСГ ім. П.Василенка. 2016. Вип. 172. С. 181-189. 
5. Сумець О.М. Логістичні витрати підприємств олійно-жирової галузі: формування та оцінювання: монографія. Харків: Видавництво НУА, 2017. 243 с.

6. Уотерс Д. Логистика. Управление цепью поставок / Д. Уотерс: пер. с англ. В.Н. Егорова. М.: ЮНИТИ-ДАНА, 2015. 503 с.

7. Буркинський Б.В., Нікішина О.В. Принципи формування ефективних логістичних ланцюгів товарних ринків: монограф. Одеса: ІПРЕЕД НАН України, 2019. 80 с.

8. Нікішина О. В. Механізми регулювання інтегрованого зернового ринку: монографія. Одеса: ІПРЕЕД НАН України, 2014. 450 с.

9. Система збалансованих показників (BSC) ефективності. URL: https://studme.com.ua/125906058799/informatika/sistema_sbalansirovannyh_pokazateley_bsc_effektivnosti.htm (дата звернення 01.06.2020).

10. Ізмайлова К. В. Фінансовий аналіз. К.: МАУП, 2001. 152 с.

11. Методичні рекомендації щодо розрахунку рівня економічної безпеки України. Затверджені Наказом Міністерства економічного розвитку i торгівлі України №1277 від 29.10.2013p. URL: https://zakon.rada.gov.ua/rada/show/v1277731-13\#n9 (дата звернення 01.06.2020).

12. Цілі сталого розвитку: Україна: національна доповідь: Київ: Міністерство економічного розвитку і торгівлі, 2017. $176 \mathrm{c}$.

13. Harrington E.C. The desirability function, Industrial Quality Control. 1965. vol. 21, no. 10. pp. 494-498.

14. Методика визначення монопольного (домінуючого) становища суб'єктів господарювання на ринку. Затверджена Розпорядженням Антимонопольного комітету України 5 березня 2002 p. №49-p. URL: https://zakon.rada.gov.ua/laws/show/z0317-02 (дата звернення 01.06.2020).

15. Цілі Сталого розвитку 2016-2030. URL: http://www.un.org.ua/ua/tsili-rozvytku-tysiacholittia/tsilistaloho-rozvytku (дата звернення 01.06.2020).

Стаття надійшла 16.07.2020

Стаття прийнята до друку 30.07.2020

Доступно в мережі Internet 15.10.2020

Никишина О.В.

доктор экономических наук, старший научный сотрудник, заведующий отделом рыночных механизмов и структур

Институт проблем рынка и экономико-

экологических исследований НАН Украины

Французский бульвар, 29, г. Одесса, Украина, 65044

E-mail: ksenkych@gmail.com.

ORCID ID: 0000-0002-7172-3551

\section{МЕТОДИЧЕСКИЕ ПОЛОЖЕНИЯ ДИАГНОСТИКИ ЭФФЕКТИВНОСТИ ФУНКЦИОНИРОВАНИЯ ЛОГИСТИЧЕСКИХ ЦЕПЕЙ ТОВАРНЫХ РЫНКОВ}

Статья посвящена обоснованию методического обеспечения для диагностики эффективности функционирования рыночных цепей на базе синтеза четырех научных подходов: воспроизводственного, регуляторного, концепций диаграммы сбалансированных преимуществ и устойчивого развития. Установлено логическую последовательность формирования системы сбалансированных показателей во взаимосвязи с концептуальным базисом и этапами оценочных процедур. Предложено совокупность показателей объединить в пять групп, которые по своему экономическому содержанию тяготеют к определенной концепции и одновременно связаны между собой единым целевым ориентиром - расширенное воспроизводство товародвижения в рынке и оптимизация общей добавленной стоимости в цепи. Обоснован ряд требований к диагностическим показателям.

Рассмотрены компоненты системы сбалансированных показателей по пяти направлениям диагностики: (1) формирование, перераспределение и структура добавленной стоимости; (2) эффрективность использования ресурсов (материальных и трудовых) и временные параметры цепи; (3) мощность движения внутренних и внешних материальных потоков в рыночной цепи; (4) тенденции устойчивого развития логистических цепей; (5) качество логистического обслуживания на рынке. Проанализированы составляющие группы диагностических показателей, обоснована целесообразность их включения в систему. Предложен ряд авторских показателей, в частности, воспроизводственная рентабельность, логистическая компонента добавленной стоимости, звеньевая структура логистических затрат, коэффициенты дискриминационности экспортных и внутренних цен и другие. В целом разработанная система включила 57 показателей, которые через цепь причинно-следственных связей связаны 
с интегрированной целью рыночной цепи.

Главными преимуществами методического обеспечения являются: (1) сравнительный анализ показателей эффективности между различными звеньями цепи, что позволяет определять логистические «разрывы»; (2) оценка в логистическом измерении современных тенденций рыночной экономики; (3) высокая регуляторная способность показателей, возможность их использования в качестве аналитической основы для принятия управленческих решений. Пользователями авторских методических положений являются рыночные субъекты, профильные и государственные институции, другие стейкхолдеры, заинтересованные в развитии рыночной логистики.

Ключевые слова: эффрективность, диагностика, рынок, логистическая цепь, методические положения, добавленная стоимость, система сбалансированных показателей.

\author{
Nikishyna 0. \\ Doctor of Economics, Senior Researcher \\ Head of Department of Market Mechanisms and Structures \\ Institute of Market Problems and Economic \& Ecological Research \\ of National Academy of Sciences of Ukraine \\ Frantsuzskiy boulevard, 29, Odesa, Ukraine, 65044 \\ E-mail: ksenkych@gmail.com \\ ORCID ID: 0000-0002-7172-3551
}

\title{
METHODICAL PROVISIONS OF DIAGNOSTICS OF EFFICIENCY OF FUNCTIONING OF COMMODITY MARKETS LOGISTIC CHAINS
}

The article is devoted to substantiation of methodical maintenance for diagnostics of efficiency of functioning of market chains on the basis of synthesis of four scientific approaches: reproduction, regulatory, concepts of the diagram of balanced advantages and sustainable development. The logical sequence of formation of the system of balanced indicators in relation to the conceptual basis and stages of evaluation procedures has been established. It has been proposed to unite the set of indicators into five groups, which in their economic content tend to a certain concept and at the same time are connected by a single target - expanded reproduction of commodity movement in the market and optimization of total value added in the chain. A number of requirements for diagnostic indicators have been substantiated.

The components of the system of balanced indicators in five areas of diagnosis have been considered: (1) the formation, redistribution and structure of value added; (2) resource efficiency (material and labor) and time parameters of the chain; (3) the power of internal and external material flows in the market chain; (4) trends in the sustainable development of logistics chains; (5) the quality of logistics services in the market. The components of the group of diagnostic indicators have been analyzed, the expediency of their inclusion in the system has been substantiated. A number of author's indicators have been offered, in particular, reproduction profitability, logistic component of added value, link structure of logistic expenses, coefficients of discrimination of export and domestic prices and others. In total, the developed system included 57 indicators that are linked to the integrated purpose of the market chain through a chain of causation.

The main advantages of the methodological support are the following: (1) comparative analysis of efficiency indicators between different links of the chain, which allows to determine logistical "gaps»; (2) assessment in the logistical dimension of current market economy trends; (3) high regulatory capacity of indicators, the possibility of their use as an analytical basis for management decisions. The users of the author's methodical provisions are market subjects, profile and state institutions, other stakeholders interested in the development of market logistics.

Keywords: efficiency, diagnostics, market, logistics chain, methodical provisions, added value, system of balanced indicators.

\section{References}

1. Witkowski, J. (1993). Metodologiczne podstawy strategii logistycznej w rzedsiębiorstwie. GmiL, (12), 214217.

2. Kochubei, D. (2009). Otsinka efektyvnosti funktsionuvannia lohistychnoi systemy torhovelnykh pidpryiemstv. Visnyk Kyivskoho natsionalnoho torhovelno-ekonomichnoho universytetu, (4), 59-66.

3. Sumets, O. M. (2019). Suchasni pidkhody do vyznachennia efektyvnosti lohistychnoi diialnosti pidpryiemstva ta yii otsiniuvannia. Logistika: problemyi i resheniya, (6 (85)), 32-42. 
4. Sumets, O. M. (2016). Otsinka rivnia lohistychnoho obsluhovuvannia spozhyvachiv produktsii vyrobnychykh pidpryiemstv. Visnyk KhNTUSH im. P.Vasylenka, (172), 181-189.

5. Sumets, O. M. (2017). Lohistychni vytraty pidpryiemstv oliino-zhyrovoi haluzi: formuvannia ta otsiniuvannia. Kharkiv: Vydavnytstvo. DANA.

6. Uoters, D. (2015). Logistika. Upravlenie tsepyu postavok (V. N. Egorova, Trans.). Moscow: YuNITI-

7. Burkynskyi, B. V., \& Nikishyna, O. V. (2019). Pryntsypy formuvannia efektyvnykh lohistychnykh lantsiuhiv tovarnykh rynkiv. Odesa: IPREED NAN Ukrainy.

8. Nikishyna, O. V. (2014). Mekhanizmy rehuliuvannia intehrovanoho zernovoho rynku. Odesa: IPREED NAN Ukrainy.

9. Systema zbalansovanykh pokaznykiv (BSC) efektyvnosti. Retrieved June 1, 2020, from https://studme.com.ua/125906058799/informatika/sistema_sbalansirovannyh_pokazateley_bsc_effektivnosti.htm 10. Izmailova, K. V. (2001). Finansovyi analiz. Kyiv: MAUP.

11. Metodychni rekomendatsii shchodo rozrakhunku rivnia ekonomichnoi bezpeky Ukrainy. Zatverdzheni Nakazom Ministerstva ekonomichnoho rozvytku i torhivli Ukrainy №1277 vid 29.10.2013r. (2013). Retrieved June 1, 2020, from https://zakon.rada.gov.ua/rada/show/v1277731-13\#n9

12. Tsili staloho rozvytku: Ukraina (report). (2017). Kyiv: Ministerstvo ekonomichnoho rozvytku i torhivli.

13. Harrington, E.C. (1965). The desirability function, Industrial Quality Control, 21(10), 494-498.

14. Metodyka vyznachennia monopolnoho (dominuiuchoho) stanovyshcha sub 'iektiv hospodariuvannia na rynku. Zatverdzhena Rozporiadzhenniam Antymonopolnoho komitetu Ukrainy 5 bereznia 2002 r. №49-r. (2002). Retrieved June 1, 2020, from https://zakon.rada.gov.ua/laws/show/z0317-02

15. Tsili Staloho rozvytku 2016-2030. Retrieved June 1, 2020, from http://www.un.org.ua/ua/tsili-rozvytkutysiacholittia/tsili-staloho-rozvytku

Received 16 July2020

Approved 30 July 2020

Available in Internet 15.10.2020

Цитування згідно ДСТУ 8302:2015

Нікішина О.В. Методичні положення діагностики ефективності функціонування логістичних ланцюгів товарних ринків // Економіка харчової промисловості. 2020. Т.12, вип. 3. С. 3-16. doi: 10.15673/fie.v12i3.1811

Cite as APA style citation

Nikishyna, O. (2020). Methodical provisions of diagnostics of efficiency of functioning of commodity markets logistic chains. Food Industry Economics, 12(3), 3-16. doi: 10.15673/fie.v12i3.1811 